\section{Examination of academic self-efficacy and motivation according to demographic characteristics of graduate education candidates (Cumhuriyet University example)}

\author{
Fatih Özgü1 ${ }^{1}$ \\ Gürkan Diker ${ }^{2}$
}

\author{
Lisansüstü eğitim \\ adaylarının akademik öz- \\ yeterlik ve güdülenmelerinin \\ demografik özelliklerine göre \\ incelenmesi \\ (Cumhuriyet Üniversitesi \\ örneği)
}

\begin{abstract}
The aim of this research is to examine the academic self-efficacy and motivation of candidates applying for the postgraduate education program of the Institute of Health Sciences according to the age, sex, graduated section and marital status variables. The sample of this research in the relational screening model is composed of 100 students who applied to the Physical Education and Sports Master program, which is included in the study by using appropriate sampling method. Academic Selfefficacy Scale and Academic Motivation Scale was applied to the candidates in the study. In evaluating the data; The error level was taken as .05 using Variance Analysis, Tukey test, Difference between Two Means Significance Test and Correlation Analysis. As a result, it has been found that candidates' academic selfefficacy and academic motivation scores differ significantly from their age and graduation levels.
\end{abstract}

Keywords: Academic Self-efficacy; Academic Motivation; Physical Education; Candidates; Graduate Education.

(Extended English abstract is at the end of this document)

\section{Özet}

$\mathrm{Bu}$ araştırmanın amacı sağlık bilimleri enstitüsü lisansüstü eğitim programına başvuru yapan adaylarını akademik öz-yeterlik ve güdülenmelerinin yaş, cinsiyet, mezun olunan bölüm ve medeni durum değisskenlerine göre incelenmesidir. İlişkisel tarama modelinde olan bu araștırmanın örneklemini uygun örnekleme yöntemi kullanılarak araştırmaya dahil edilen Beden Eğitimi ve Spor Yüksek Lisans programina başvuru yapan 100 öğrenci oluşturmaktadır. Araştırmada adaylara, Akademik Öz-yeterlik Ölçeği ile Akademik Güdülenme Ölçeği uygulanmıştır.

Verilerin değerlendirilmesinde; Varyans Analizi, Tukey testi, İki Ortalama Arasındaki Farkın Önemlilik Testi ve Korelasyon Analizi kullanılarak yanılma düzeyi .05 olarak alınmıştır. Sonuç olarak adayların akademik öz-yeterlik ve akademik güdülenme puanlarının yaşa ve mezun oldukları bölümlere göre anlamlı ölçüde farklılaştığı tespit edilmiştir.

Anahtar Kelimeler: Akademik Öz-yeterlik; Akademik Güdülenme; Adaylar; Beden Eğitimi; Lisansüstü Eğitim.

\footnotetext{
1 Assist. Prof. Dr, Cumhuriyet University, Physical Education and Sports High School, Physical Education Teaching, fozgul@,cumhuriyet.edu.tr

2 Lecturer, Cumhuriyet University, Physical Education and Sports High School, Physical Education Teaching, gdiker@,cumhuriyet.edu.tr
} 
Özgül, F., \& Diker, G. (2017). Lisansüstü eğitim adaylarının akademik öz-yeterlik ve güdülenmelerinin incelenmesi (Cumhuriyet Üniversitesi örneği). Journal of Human Sciences, 14(2), 2129-2139. doi:10.14687/ihs.v14i2.4411

\section{Giriş}

Günümüzde üniversitelerin gerekli bilimsel yeterliliklere sahip kişiler yetiştirme şekli yüksek lisans ve doktora çalışmalarına dönüşmüştür. Bunun nedeni olarak bilgi ve teknolojilerin hızlı değişimi gösterilebilir. Lisansüstü eğitim bireye bilimsel anlamda kendisini geliştirme açısından imkan tanımaktadır. Lisansüstü eğitimde öğrencilere çeşitli faydalar sağlanmaktadır. Bunlar; teknolojik yardımlar, danışmalık hizmetleri ve bilimsel çalışmaları öğrenerek uygulama fırsatı sağlamaktadır. Bu sebeple lisansüstü öğretimin olanak ve içerik bakımından lisans öğretiminden farklı olarak gerçekleştirilmesi beklenir (Güven ve Tunç, 2007). Özellikle ülke problemlerine ilişkin sonuçlar ortaya koyma ve ihtiyaç hissedilen yüksek nitelikteki insan gücünü yetiştirme açısından lisansüstü öğretim önemli sorumluluklar taşımaktadır (Karakütük, 2002). Bununla birlikte etik değerlere saygılı, yaratıcı çözümler üretebilen, grup çalışmasına yatkın, uyumlu ve toplum gereksinimlerine cevap verebilen bireyler yetiştirmek lisansüstü öğretimin amaçlarındandır. Lisansüstü Eğitim Öğretim Yönetmeliğgi (1996) ve Bologna süreci dahilinde geliştirilen Türkiye Yükseköğretim Yeterlilikler Çerçevesi özet raporuna göre; lisansüstü eğitim yüksek lisans ve doktora olmak üzere iki bölümde incelenerek, lisansüstü mezunlarının yeterlikleri belirlenmiştir (Türkiye Yükseköğretim Yeterlilikler Çerçevesi, 2010). Buna karşın lisansüstü öğretim birtakım sorunları da adaylarına sunmaktadır. Bu sorunların başında ekonomik problemler gelmektedir. Ekonomik problemleri aşabilmek için çok sayıda ülkede kamu kurumları ve özel vakıflar lisansüstü öğretim adaylarını burslarla desteklemektedir (Tural, 1993). Bu probleme ek olarak insan davranışlarındaki farklılıklar da merak edilen diğer bir problemdir. İnsanların eylemlerini belirlerken bazı hareketleri neden tercih ettiği yıllardır araştırmalara konu olmuştur (Açıkgöz, 2007). Güdü, belirlenen amaçlara ulaşabilmek ve gerekli davranışları gösterebilmek için bireyi harekete geçirerek yönlendiren itici bir güçtür (Balaban Sal1, 2006). Genel güdüler, organizmanın ihtiyaçlarından doğar. Bireyler ulaşmak veya kaçınmak istedikleri şeyler için çaba göstermek, planlamak, düzenlemek, tekrarlamak, izlemek, karar almak, problem çözmek ve süreci değerlendirmek gibi bilişsel faaliyetler içerisine gireceklerdir (Pintrich ve Schunk, 1996). Güdü kavramı, 1930'lardan itibaren öğrenme kuramlarına paralel olarak davranışçllıktan bilişselciliğe giden bir yol izlemiştir. İlk zamanlarda dürtü, içgüdü gibi kavramlara dayandırılan güdü; günümüzde nedensel yüklemeler, öz yeterlilik, kontrol ve amaç gibi kavramlara dayandırılmaktadır (Açıkgöz, 2007). Akademik güdülenme ise, kısaca "akademik işler için gerekli enerjinin üretilmesi” olarak tanımlanmaktadır (Bozanoğlu, 2004). Güdü (motivasyon), öğrenme sürecinin merkezi faktörlerinden biridir (Kelley, 2002; akt. Aggarwal, 2004). İnsanların ulaşmak istedikleri için güdülenmesi, onların başarıya ulaşma șansını ne kadar yüksek gördüğüne ve başarmak istediğini ne kadar değerli bulduğuna bağlıdır (Duy ve Kaya, 2009). Bu yüzden, öğrencilerin güdülerini etkileyen faktörlerin tespit edilerek gerekli önlemlerin alınması ve özellikle öğrenme ve öğretme süreçlerinin daha etkili ve verimli hale getirilmesi akademik başarı açısından önemli olacaktır (Karataş ve Erden, 2012).

Bireylerin kendini değerlendirmesi sosyal öğrenme kuramının en önemli ilkesidir. Bireyler düşüncelerine uygun eylemde bulunduktan sonra, eylemlerinin sonuçlarını değerlendirebilir ve kendilerini yargılayabilirler. Bu süreçte insanın kendinin farkında olması ve öğrenme kapasitesi ile yapacağı iş arasında değerlendirme yapması, öğrenme sürecinde önemli bir durumdur. Bu olgu 'Öz-yeterlik' kavramıyla açıklanmıştır (Korkmaz, 2004; akt. Özsüer ve ark., 2011). 'Öz-yeterlik' Bandura (1977)'nın sosyal öğrenme kuramında bulunan temel kavramlardan biridir ve "bireyin olası durumlar ile başa çıkabilmesi için gerekli olan eylemleri ne kadar iyi yapabileceğine ilisskin inancı" olarak tanımlamaktadır (Akkoyunlu ve Kurbanoğlu, 2004). Bandura (1995; 1977)'ya göre, bireyin davranışlarında oldukça önemli olan öz-yeterlik inançlarının; "bireyin daha önceki başarı ve/veya başarısızlık deneyimlerini içeren performans başarıları", "başkalarının yapmış olduğu etkinliklerin sonuçlarından elde edilen deneyimler", "bireyin yapabileceği etkinlikler konusunda sözel olarak ikna edilmesi" ve "bireyin fiziksel/ duygusal durumu" olmak üzere dört kaynağ1 bulunmaktadır. Bu dört kaynağa bağlı olarak ortaya çıkan birçok davranışa ilişkin öz-yeterlik algısı vardır. Öğrenme etkinlikleri düşünüldügünde ise akademik öz-yeterlik alg1sı daha fazla öne 
Özgül, F., \& Diker, G. (2017). Lisansüstü eğitim adaylarının akademik öz-yeterlik ve güdülenmelerinin incelenmesi (Cumhuriyet Üniversitesi örneği). Journal of Human Sciences, 14(2), 2129-2139. doi:10.14687/jhs.v14i2.4411

çıkmaktadır (Tabancalı ve Çelik, 2013). Lisansüstü eğitim adaylarının akademik öz-yeterlik ve güdülenme düzeylerinin belirlenmesi, eğitimlerinin devamlllı̆̆ ve alanlarına verecekleri katkılar açısından önem arz etmektedir.

$\mathrm{Bu}$ araştırmanın amacı sağlık bilimleri enstitüsü lisansüstü eğitim adaylarının akademik özyeterlik ve güdülenmelerinin yaş, cinsiyet, mezun olunan bölüm ve medeni durum değişkenlerine göre karşılaştırılmasıdır.

\section{Yöntem}

\section{Araştırma Modeli}

$\mathrm{Bu}$ çalışmanın modeli ilişkisel tarama niteliğindedir. Araştırmada lisansüstü eğitim adaylarının akademik öz-yeterlik ve akademik güdülenme düzeyleri bazı değişkenler açısından karşılaştırılmıştır. Tarama modeli geçmişte veya halen var olan durumu var olduğu şekilde betimlemeyi amaçlayan bir araştırma yaklaşımıdır (Balc1, 2001).

\section{Çalışma Grubu}

Araştırmanın evrenini 2016-2017 eğitim-öğretim yılında Cumhuriyet Üniversitesi Sağlık Bilimleri Enstitüsünde açılan lisansüstü eğitim programlarına başvuran öğrenciler oluşturmaktadır. Araştırmanın örneklemini ise; uygun örnekleme yöntemi kullanılarak araştırmaya dahil edilen Beden Eğitimi ve Spor Yüksek Lisans programına başvuran 100 öğrenci oluşturmaktadır. Uygun örneklem; seçkisiz olmayan (nonrandom sampling) yöntemlerden birisi olan uygun örnekleme (convenience sampling) yöntemiyle (Fraenkel ve Wallen, 2006) örneklem seçimidir.

Araştırmaya dahil olan adayların kişisel özelliklerine göre dağılımları: adayların 39 (\% 39)'u kadın, 61 (\% 61)'i erkek; 20-25 yaş aralığında 46 (\% 46) aday, 26-31 yaş aralığında $29(\%$ 29) aday ve 32-37 yaş aralığında 25 (\% 25) aday; 26 (\% 26) aday evli ve 74 (\% 74) aday bekar; adayların 16 (\% 16)'s1 Antrenörlük Bölümü mezunu, 54 (\% 54)'ü Öğretmenlik ve 30 (\% 30)'u Spor Yöneticiliği mezunu şeklindedir.

\section{Veri Toplama Araçları}

$\mathrm{Bu}$ araştırmada veri toplamak için iki farklı ölçek kullanımıştır. Araştırmada, Owen ve Froman (1988) tarafindan geliştirilen ve Ekici (2012) tarafindan Türkçe'ye çevrilerek geçerlikgüvenirlik çalışması yapılan Akademik Öz-yeterlik ölçeği ile Bozanoğlu (2004) tarafından geliştirilen Akademik Güdülenme Ölçeği kullanılmıştır.

Akademik Öz-yeterlik Ölçeği; sosyal statü, bilişsel uygulamalar ve teknik beceriler olmak üzere 3 boyut ve toplam 33 maddeden oluşmaktadır. Ölçek 5'li likert tipinde hazırlanmıştır. Ölçekte yer alan ifadeler; Oldukça Az (1 Puan), Az (2 Puan), Kısmen Fazla (3 Puan), Fazla (4 Puan), Oldukça Fazla (5 Puan) şeklinde sıralanmaktadır. Ölçeğin genelinden veya alt boyutlarından alınabilecek en düşün puan 33, en yüksek puan ise 165 puandır. Ölçeğin iç tutarlılık katsayısı da .86 olarak hesaplanmıştır. Akademik Güdülenme Ölçeği ise, 20 maddeden oluşmaktadır ve her bir madde yanıtlayıcıya uygunluk bakımından 5'li dereceleme olanağ1 sunmaktadır (1=Hiç Katılmıyorum, 5=Tamamen Katıllyorum). Ölçekte sadece bir madde (4. madde) tersine puanlanmaktadır. Ölçeğin Cronbach alpha güvenirlik katsayısı .87 olarak tespit edilmiştir. Üç faktörlü (Kendini Aşma, Bilgiyi Kullanma, Keşif) bir yapıya sahip olan ölçeğin, faktörlerin açıkladığı varyanslar ve faktörler altında yer alan maddelerin içerikleri incelendiğinde tek boyutlu olarak da kullanılabileceği önerilmektedir.

\section{Verilerin Toplanmas1}

Araştırmada kullanılan veri toplama araçlarının uygulanması için gerekli izinler alınmıştır. Uygulama öncesinde araştırmanın amacına ilişkin gerekli açıklamalar yapılmış ve adaylar Bilgilendirilmiş Gönüllü Onam Formlarını doldurmuşlardır. Sonrasında ölçeklerin doldurulmasına 
geçilmiş, yanlış doldurulan formlar geçersiz sayılarak, kabul edilebilir nitelikte olan formlar (100) değerlendirilmek için bilgisayara aktarılmıştır.

\section{Verilerin Analizi}

Çalışmadan elde edilen verilerin analizinde SPSS (Ver:23.0) programı kullanılmıştır. Verilerin değerlendirilmesinde parametrik test varsayımları yerine getirildiğinden (KolmogorovSmirnov), bağımsız ikiden fazla grup karşılaştırılırken; Varyans Analizi, Tukey testi, bağımsız iki grup karşılaştırılırken; İki Ortalama Arasındaki Farkın Önemlilik Testi ve Korelasyon Analizi uygulanarak yanılma düzeyi $(\alpha) .05$ olarak alınmıştır.

\section{Bulgular}

Lisansüstü eğitim adaylarının yaş gruplarına göre akademik öz-yeterlik alt boyut ve toplam puanları ile akademik güdülenme toplam puanları Tablo 1'de verilmiştir.

Tablo 1. Akademik öz-yeterlik alt boyut ve toplam puanları ile Akademik Güdülenme toplam puanlarının Yaş gruplarına göre karşılaştırılması (One Way ANOVA)

\begin{tabular}{|c|c|c|c|c|c|c|c|}
\hline Akademik Öz-yeterlik & Yaş & $\mathbf{N}$ & Ort. & Std. Sapma & Min & Max & Sonuç \\
\hline \multirow{3}{*}{$\begin{array}{l}\text { Sosyal Statü } \\
\text { Boyutu }\end{array}$} & $20-25$ & 46 & 36.82 & 5.93 & 26.00 & 48.00 & $F=4.58$ \\
\hline & $26-31$ & 29 & 34.82 & 6.46 & 22.00 & 45.00 & \multirow[t]{2}{*}{$\mathrm{P}=0.015^{*}$} \\
\hline & $32--37$ & 25 & 42.00 & 5.22 & 35.00 & 49.00 & \\
\hline \multirow{3}{*}{$\begin{array}{l}\text { Teknik Beceri } \\
\text { Boyutu }\end{array}$} & $20-25$ & 46 & 15.34 & 2.74 & 11.00 & 20.00 & $\mathrm{~F}=4.02$ \\
\hline & $26-31$ & 29 & 13.88 & 2.34 & 9.00 & 17.00 & \multirow[t]{2}{*}{$\mathrm{P}=0.024^{*}$} \\
\hline & $32--37$ & 25 & 16.50 & 1.35 & 15.00 & 18.00 & \\
\hline \multirow{3}{*}{$\begin{array}{l}\text { Bilişsel Uygulama } \\
\text { Boyutu }\end{array}$} & $20-25$ & 46 & 74.43 & 9.35 & 53.00 & 89.00 & \multirow{3}{*}{$\mathrm{P}=0.095$} \\
\hline & $26-31$ & 29 & 70.94 & 12.38 & 48.00 & 97.00 & \\
\hline & $32--37$ & 25 & 80.00 & 7.65 & 68.00 & 91.00 & \\
\hline \multirow{3}{*}{$\begin{array}{l}\text { Toplam Akademik } \\
\text { Öz-Yeterlilik }\end{array}$} & $20-25$ & 46 & 126.60 & 16.25 & 93.00 & 154.00 & $\mathrm{~F}=4.16$ \\
\hline & $26-31$ & 29 & 119.64 & 18.15 & 84.00 & 146.00 & \multirow[t]{2}{*}{$\mathrm{P}=0.022^{*}$} \\
\hline & $32--37$ & 25 & 138.50 & 13.14 & 120.00 & 157.00 & \\
\hline \multirow{3}{*}{$\begin{array}{l}\text { Toplam Akademik } \\
\text { Güdülenme }\end{array}$} & $20-25$ & 46 & 82.17 & 7.54 & 68.00 & 94.00 & $\mathrm{~F}=5.48$ \\
\hline & $26-31$ & 29 & 76.35 & 7.42 & 64.00 & 86.00 & \multirow[t]{2}{*}{$\mathrm{P}=0.007^{*}$} \\
\hline & $32--37$ & 25 & 85.30 & 6.32 & 78.00 & 95.00 & \\
\hline
\end{tabular}


Tablo 1'de yaş gruplarına göre bireylerin sosyal statü alt boyut puanları karşılaştırıldığında, 26-31 ile 32-37 yaşlar arasındaki farklılık anlamlı bulunurken $(p<0.05)$, diğer yaş grupları arası farklılık anlamsız bulunmuştur ( $\mathrm{p}>0.05)$. Teknik beceri alt boyut puanları karşılaştırıldığında, yine 26-31 ile 32-37 yaşlar arasındaki farklılık önemli bulunmuştur $(\mathrm{p}<0.05)$. Bilişsel uygulamalar alt boyut puanları karşılaştırıldığında, yaş grupları arasında anlamlı bir farklılık bulunamamıştır ( $\mathrm{p}>0.05)$. Toplam akademik öz-yeterlik puanları karşılaştırıldığında, yine 26-31 ile 32-37 yaşlar arasındaki farklılık önemli bulunurken $(\mathrm{p}<0.05)$, diğer yaş grupları arasındaki farklılık önemsiz bulunmuştur ( $\mathrm{p}>0.05)$. Toplam akademik güdülenme puanları karşılaştırıldığında ise, hem 20-25 yaş ile 26-31 yaş arasında hem de 26-31 yaş ile 32-37 yaşlar arasındaki farklılık önemli bulurken ( $p<0.05), 20-25$ yaş ile 32-37 yaşlar arasındaki farklılık önemsiz bulunmuştur ( $p>0.05)$.

Tablo 2. Akademik Öz-yeterlik alt boyutları ve toplam puanları ile Akademik Güdülenme toplam puanlarının Bölümlere göre Karşılaştırılması (One Way ANOVA)

\begin{tabular}{|c|c|c|c|c|c|c|c|}
\hline Akademik Öz-yeterlik & Bölüm & $\mathbf{N}$ & Ort. & Std.Sapma & Min & Max & Sonuç \\
\hline \multirow{3}{*}{$\begin{array}{l}\text { Sosyal Statü } \\
\text { Boyutu }\end{array}$} & Antrenörlük & 16 & 36.25 & 6.60 & 22.00 & 45.00 & $F=3.48$ \\
\hline & Öğretmenlik & 54 & 39.18 & 6.40 & 27.00 & 49.00 & $\mathrm{P}=0.039 *$ \\
\hline & Yöneticilik & 30 & 34.06 & 5.24 & 26.00 & 43.00 & \\
\hline \multirow{3}{*}{$\begin{array}{l}\text { Teknik Beceri } \\
\text { Boyutu }\end{array}$} & Antrenörlük & 16 & 14.87 & 2.53 & 11.00 & 19.00 & $\mathrm{~F}=0.64$ \\
\hline & Öğretmenlik & 54 & 15.44 & 2.48 & 9.00 & 20.00 & $\mathrm{P}=0.530$ \\
\hline & Yöneticilik & 30 & 14.53 & 2.69 & 11.00 & 20.00 & \\
\hline \multirow{3}{*}{$\begin{array}{l}\text { Bilişsel Uygulama } \\
\text { Boyutu }\end{array}$} & Antrenörlük & 16 & 72.25 & 11.58 & 49.00 & 89.00 & $\mathrm{~F}=1.45$ \\
\hline & Öğretmenlik & 54 & 76.66 & 11.46 & 48.00 & 97.00 & $\mathrm{P}=0.243$ \\
\hline & Yöneticilik & 30 & 71.33 & 7.31 & 58.00 & 83.00 & \\
\hline \multirow{3}{*}{$\begin{array}{l}\text { Toplam Akademik } \\
\text { Öz-Yeterlilik }\end{array}$} & Antrenörlük & 16 & 123.37 & 19.66 & 84.00 & 153.00 & $\mathrm{~F}=2.33$ \\
\hline & Öğretmenlik & 54 & 131.29 & 18.05 & 91.00 & 157.00 & $\mathrm{P}=0.108$ \\
\hline & Yöneticilik & 30 & 119.93 & 12.94 & 102.00 & 143.00 & \\
\hline \multirow{3}{*}{$\begin{array}{l}\text { Toplam Akademik } \\
\text { Güdülenme }\end{array}$} & Antrenörlük & 16 & 80.87 & 8.09 & 65.00 & 93.00 & $\mathrm{~F}=1.42$ \\
\hline & Öğretmenlik & 54 & 82.33 & 8.12 & 64.00 & 95.00 & $\mathrm{P}=0.251$ \\
\hline & Yöneticilik & 30 & 78.06 & 7.18 & 66.00 & 90.00 & \\
\hline
\end{tabular}

$*_{\mathrm{p}}<0.05$ düzeyinde anlamlı

Tablo 2'de araştırmaya katılan lisansüstü eğitim adaylarının bölümlere göre sosyal statü alt boyut puanları karşılaştırıldığında. farklılık önemli bulunmuştur $(\mathrm{p}<0.05)$. Puanlar ikişerli karşılaştırıldığında ise; öğretmenlik ile yöneticilik arasındaki farklılık önemli bulunurken $(\mathrm{p}<0.05)$. diğer bölümler arası farklll1k önemsiz bulunmuştur $(p>0.05)$. Bölümlere göre bireylerin teknik 
beceri ve bilişsel uygulamalar alt boyut puanları ile toplam akademik öz-yeterlik ve toplam akademik güdülenme puanları karşılaştırıldığında ise. farklılık önemsiz bulunmuştur ( $\mathrm{p}>0.05)$.

Tablo 3. Akademik Öz-yeterlik alt boyutları ve toplam puanları ile Akademik Güdülenme toplam puanlarının Cinsiyete göre Karşılaştırılması (Independent Samples Test)

\begin{tabular}{|c|c|c|c|c|c|c|c|}
\hline Akademik Öz-yeterlik & Cinsiyet & $\mathbf{N}$ & Ort. & Std.Sapma & Min & Max & Sonuç \\
\hline \multirow{2}{*}{$\begin{array}{l}\text { Sosyal Statü } \\
\text { Boyutu }\end{array}$} & Kadin & 39 & 35.55 & 6.35 & 22.00 & 48.00 & $\mathrm{t}=0.49$ \\
\hline & Erkek & 61 & 38.26 & 6.33 & 26.00 & 49.00 & $\mathrm{P}=0.625$ \\
\hline \multirow{2}{*}{$\begin{array}{l}\text { Teknik Beceri } \\
\text { Boyutu }\end{array}$} & Kadın & 39 & 15.30 & 2.97 & 9.00 & 20.00 & $\mathrm{t}=1.48$ \\
\hline & Erkek & 61 & 14.93 & 2.24 & 11.00 & 18.00 & $\mathrm{P}=0.144$ \\
\hline \multirow{2}{*}{$\begin{array}{l}\text { Bilişsel Uygulama } \\
\text { Boyutu }\end{array}$} & Kadin & 39 & 75.15 & 9.72 & 49.00 & 89.00 & $\mathrm{t}=0.49$ \\
\hline & Erkek & 61 & 73.83 & 11.15 & 48.00 & 97.00 & $\mathrm{P}=0.625$ \\
\hline \multirow{2}{*}{$\begin{array}{l}\text { Toplam Akademik } \\
\text { Öz-Yeterlilik }\end{array}$} & Kadın & 39 & 126.00 & 17.89 & 84.00 & 154.00 & $\mathrm{t}=0.43$ \\
\hline & Erkek & 61 & 127.03 & 17.40 & 91.00 & 157.00 & $\mathrm{P}=0.669$ \\
\hline \multirow{2}{*}{$\begin{array}{l}\text { Toplam Akademik } \\
\text { Güdülenme }\end{array}$} & Kadın & 39 & 81.50 & 7.75 & 65.00 & 93.00 & $\mathrm{t}=0.20$ \\
\hline & Erkek & 61 & 80.36 & 8.13 & 64.00 & 95.00 & $\mathrm{P}=0.840$ \\
\hline
\end{tabular}

Araştırmaya dahil olan adayların cinsiyete göre akademik öz-yeterlik alt boyut ve toplam puanları ile akademik güdülenme toplam puanları karşılaştırıldığında. aradaki farklılık anlamsız bulunmuştur ( $\mathrm{p}>0.05)$.

Tablo 4. Akademik Öz-yeterlik alt boyutları ve toplam puanları ile Akademik Güdülenme toplam puanlarının Medeni Durumlarına göre Karşılaştırılması (Independent Samples Test)

\begin{tabular}{|c|c|c|c|c|c|c|c|}
\hline Akademik Öz-yeterli & Med.Dur. & $\mathbf{N}$ & Ort. & Std.Sapma & Min & Max & Sonuç \\
\hline \multirow{2}{*}{$\begin{array}{l}\text { Sosyal Statü } \\
\text { Boyutu }\end{array}$} & Evli & 26 & 38.38 & 6.93 & 26.00 & 48.00 & $\mathrm{~T}=0.18$ \\
\hline & Bekar & 74 & 36.75 & 6.27 & 22.00 & 49.00 & $\mathrm{P}=0.852$ \\
\hline \multirow{2}{*}{$\begin{array}{l}\text { Teknik Beceri } \\
\text { Boyutu }\end{array}$} & Evli & 26 & 14.84 & 2.70 & 9.00 & 18.00 & $\mathrm{~T}=0.78$ \\
\hline & Bekar & 74 & 15.16 & 2.51 & 11.00 & 20.00 & $\mathrm{P}=0.437$ \\
\hline \multirow{2}{*}{$\begin{array}{l}\text { Bilişsel Uygulama } \\
\text { Boyutu }\end{array}$} & Evli & 26 & 73.76 & 8.24 & 62.00 & 89.00 & $\mathrm{~T}=0.38$ \\
\hline & Bekar & 74 & 74.56 & 11.30 & 48.00 & 97.00 & $\mathrm{P}=0.704$ \\
\hline \multirow{2}{*}{$\begin{array}{l}\text { Toplam Akademik } \\
\text { Öz-Yeterlilik }\end{array}$} & Evli & 26 & 127.00 & 16.90 & 99.00 & 152.00 & $\mathrm{~T}=0.23$ \\
\hline & Bekar & 74 & 126.48 & 17.83 & 84.00 & 157.00 & $\mathrm{P}=0.817$ \\
\hline \multirow{2}{*}{$\begin{array}{l}\text { Toplam Akademik } \\
\text { Güdülenme }\end{array}$} & Evli & 26 & 80.46 & 9.56 & 66.00 & 95.00 & $\mathrm{~T}=0.009$ \\
\hline & Bekar & 74 & 80.94 & 7.40 & 64.00 & 94.00 & $\mathrm{P}=0.928$ \\
\hline
\end{tabular}


Özgül, F., \& Diker, G. (2017). Lisansüstü eğitim adaylanının akademik öz-yeterlik ve güdülenmelerinin incelenmesi (Cumhuriyet Üniversitesi örneği). Journal of Human Sciences, 14(2), 2129-2139. doi:10.14687/jhs.v14i2.4411

Araştırmaya katılan adayların medeni durumlarına göre toplam akademik öz-yeterlik ve alt boyut puanları ile toplam akademik güdülenme puanları karşılaştırıldığında yine anlamlı farklılık bulunamamıştır ( $\mathrm{p}>0.05)$.

Tablo 5. Akademik Güdülenme ile Akademik Öz-yeterlik ve alt boyut değişkenleri arasındaki İlişkinin İncelenmesi (Pearson Korelasyon Analizi)

\begin{tabular}{llllll}
\hline & $\begin{array}{l}\text { Sosyal } \\
\text { Statü } \\
\text { Boyutu }\end{array}$ & $\begin{array}{l}\text { Teknik } \\
\text { Beceri } \\
\text { Boyutu }\end{array}$ & $\begin{array}{l}\text { Bilişsel } \\
\text { Uygulama } \\
\text { Boyutu }\end{array}$ & $\begin{array}{l}\text { Toplam } \\
\text { Akademik } \\
\text { Öz-Yeterlilik }\end{array}$ \\
\hline $\begin{array}{l}\text { Toplam Akademik } \\
\text { Güdülenme }\end{array}$ & $\mathbf{r}$ & $.64^{*}$ & $.48^{*}$ & $.65^{*}$ & $.70^{*}$ \\
& $\mathbf{p}$ & .000 & .000 & .000 & .000 \\
& $\mathbf{n}$ & 100 & 100 & 100 & 100 \\
\hline
\end{tabular}

${ }^{*} \mathrm{p}<0.01$ düzeyinde anlamlı

Tablo 5'de Akademik güdülenme ile akademik öz-yeterlik arasındaki korelasyon analizi verilmiştir. Buna göre; toplam akademik güdülenme ile sosyal statü alt boyutu arasında aynı yönlü $(\mathrm{r}=0.64)$, teknik beceri alt boyutu arasında aynı yönlü $(\mathrm{r}=0.48)$, bilişsel uygulama alt boyutu arasında aynı yönlü $(\mathrm{r}=0.65)$ ve toplam akademik öz-yeterlik arasında aynı yönlü $(\mathrm{r}=0.70)$ ilişki katsayıları bulunmuştur. Bulunan bu ilişki katsayılarının tamamı istatistiksel olarak anlamlıdır $(\mathrm{p}<0.01)$. Buna göre; toplam akademik güdülenme arttığında toplam akademik öz-yeterlik ve alt boyutları da artmaktadir.

\section{Tartı̧̧ma}

Araştırmaya katılan lisansüstü eğitim adaylarının akademik öz-yeterlik alt boyut ve toplam puanları ile toplam akademik güdülenme puanları yaş gruplarına göre karşılaştırıldığında hem akademik öz-yeterlik alt boyutları ve toplam puanları açısından hem de akademik güdülenme toplam puanları açısından anlamlı farklılıklar bulunmuştur. Bunun sebebi olarak yaş değişkeninin hem akademik öz-yeterlik toplam ve alt boyut puanlarını hem de akademik güdülenme toplam puanlarını etkilediği bu çalışamaya göre ifade edilebilir. Bu sonucu destekler nitelikte. Tabancalı ve Çelik (2013) çalışmalarında akademik öz-yeterlik puanlarının yaşa göre farklılaştı̆̆ını belirtmişlerdir. Fırat Durdukoca (2010) ve Kılıç ve Öncü (2013) tarafından yapılan çalışmalarda da akademik özyeterlik puan ortalamalarının orta seviyenin üzerinde olduğu görülmektedir. Araştırmada yer alan adayların akademik öz-yeterlik alt boyutlarından sosyal statü alt boyut puanları mezun oldukları bölümlere göre incelendiğinde. anlamlı farklılıklar bulunmuştur. Puanlar ikisserli karşılaştırıldığında ise, beden eğitimi öğretmenliği ile spor yöneticiliği bölümleri arasındaki farkllık anlamlı çıkarken, beden eğitimi öğretmenliği bölümü ile antrenörlük bölümü ile aralarındaki fark önemsiz çıkmıştır. Sosyal statü alt boyutunda bulunan anlamlı farkl1lı beden eğitimi öğretmenleri ve spor yöneticilerinin kurumsal kimlik kazanarak iş hayatının içerisinde olmalarından kaynaklandığ1 şeklinde yorumlanabilir. Çakır, Kan ve Sünbül (2006) ve Demirtaş, Cömert ve Özer (2011)'in yapmış oldukları çalışmalarda sosyal alanlarda öğrenim gören öğretmen adaylarının, fen ve matematik alanlarında öğenim gören öğretmen adaylarına oranla akademik öz-yeterliklerinin daha yüksek olduğu belirtilmiştir.

Araştırma sonucunda Toplam Akademik Öz-yeterlik ve Toplam Akademik Güdülenme puanlarının cinsiyete göre farklılaşmadığı tespit edilmiştir. Bu sonucu destekler nitelikte; Saracaloğlu (2008). 'Lisansüstü Öğrencilerin Akademik Güdülenme Düzeyleri. Araştırma Kaygıları ve 
Özgül, F., \& Diker, G. (2017). Lisansüstü eğitim adaylanının akademik öz-yeterlik ve güdülenmelerinin incelenmesi (Cumhuriyet Üniversitesi örneği). Journal of Human Sciences, 14(2), 2129-2139. doi:10.14687/jhs.v14i2.4411

Tutumları ile Araştırma Yeterlikleri Arasındaki İlişki’ isimli araştırmasında öğrencilerin akademik güdülenme puanlarının cinsiyet, öğrenim düzeyi ve mesleğe göre anlamlı bir değişim göstermediğini ifade etmiştir. Eğmir ve ark. (2013) "Lisansüstü Eğitim Gören Öğrencilerin Akademik Güdülenme Düzeyleri" isimli araştırmalarında da akademik güdülenme düzeylerinin cinsiyete göre anlamlı ölçüde farklılaşmadığını belirtmişlerdir. Yine. Semerci ve Duman (2013) yaptıkları çalışmada Bilgisayar ve Öğretim Teknolojileri Öğretmenliğinde öğrenim gören öğrencilerin akademik güdülenme düzeylerinin cinsiyete göre farklllık göstermediğini tespit etmişlerdir. Çakar ve Şahin (2011) tarafindan yapılan "Eğitim Fakültesi Öğrencilerinin Öğrenme Stratejileri ve Akademik Güdülenme Düzeylerinin Akademik Başarılarına Etkisi” isimli çalıșmada da, cinsiyet değișkeninin akademik güdülenme düzeylerinde anlamlı bir farka neden olmadığı belirtilmiştir. Araştırmaya göre, akademik öz-yeterlik alt boyut ve toplam puanları ile akademik güdülenme toplam puanlarının cinsiyete göre değişiklik göstermemesi, adayların lisans eğitimi sürecinde farklı aşamalardan geçmemeleri hatta günümüzde kadın-erkek arasındaki eşitsizliklerin giderek azalması olarak açılanabilir.

Buna karşın; Eymur ve Geban (2011)'nın öğretmen adaylarının akademik motivasyon ve akademik başarılarını inceledikleri çalışmada ise yedi motivasyon alt ölçeğinden yalnızca "içsel motivasyon/ uyarım yaşama" alt boyutunda istatistiksel olarak anlamlı bir farklılık olduğu tespit edilmiş. kadınların akademik motivasyon puanları. erkeklerin akademik motivasyon puanlarına göre daha yüksek bulunmuştur. Ülkemizde. beden eğitimi öğretmeni adaylarının öğretmenlik mesleğine yönelik motivasyonlarının incelendiği çalışmalarda. Gençay ve Gençay (2007) kadın öğretmen adaylarının. Tekin ve ark. (2009) de erkek öğretmen adaylarının daha yüksek motivasyon düzeyine sahip olduklarını tespit etmişlerdir.

Araştırmaya katılan lisansüstü eğitim adaylarının akademik öz-yeterlik alt boyut ve toplam puanları ile toplam akademik güdülenme puanları medeni durumlarına göre karşılaştırıldığında hem akademik öz-yeterlik alt boyutları ve toplam puanları açısından hem de akademik güdülenme toplam puanları açısından anlamlı farkllikklar bulunamamışır. Bu çalışmaya göre, medeni durum değişkeninin lisansüstü eğitim adaylarının akademik öz-yeterlik ve akademik güdülenme inançlarını değiştirmediği sonucu ifade edilebilir.

Araştırmada yer alan lisansüstü eğitim adaylarının akademik öz-yeterlik ile akademik güdülenmeleri arasında yüksek düzeyde anlamlı ve pozitif ilişki bulunmuştur. Araştırma sonucuna paralel olarak, lisans öğrencileri üzerinde yapılan bir çalısmada Akbay ve Gizir (2010) akademik özyeterlik ile akademik güdülenme arasında yüksek düzeyde anlamlı ve pozitif bir ilişki olduğu tespit edilmiştir. Aydın (2010) çalışmasında, lise öğrencilerinin akademik güdülenme, öz-yeterlik ve sınav kaygısının akademik başarı ile ilişkilendirmiş ve sonuç olarak öğrencilerin akademik güdülenmeleri ile akademik öz-yeterlikleri arasında yine pozitif yönde bir ilişki olduğunu saptamıştır. Benzer şekilde, Turgut (2013), lisans öğrencilerinin akademik öz-yeterlik inançları ile akademik performans ve sinıf düzeyleri arasında orta düzeyde bir ilişki olduğunu tespit etmiştir. Yine Bedel (2016) araştırmasında, öğretmen adaylarının akademik öz-yeterlikleri ile akademik motivasyonları arasında anlamlı bir ilişki saptamıştır. Bu araştırmaya göre akademik güdülenme özelliği yükseldikçe akademik öz-yeterlik özelliği de yükselmektedir. Bireylerin akademik güdülenme ile akademik işler için gereken enerjiyi toplayabilmeleri bunun sonucu olarak ifade edilebilir.

\section{Sonuç}

Lisansüstü eğitim adaylarının akademik öz-yeterlikleri ile akademik güdülenme algılarını kişisel bilgilerinden elde edilen bağımsız değişkenlere göre incelemek ve aralarındaki ilişkiyi belirlemek amacıyla yapılan bu araştırma sonucunda araştırma grubunun akademik öz-yeterlik ve akademik güdülenme alg1larının orta seviyenin üzerinde olduğu görülmüştür. Araştırma sonucunda 26-31 ile 32-37 yaşlar arasında akademik öz-yeterlik alt boyutlarından sosyal statü ve teknik beceriler yeterlikleri anlamlı ölçüde farklılaşmıştır. Aynı zamanda yaşa göre akademik güdülenme seviyelerinde de anlamlı farklılıklar tespit edilmiştir. Araştırma sonucunda akademik öz-yeterlik alt 
Özgül, F., \& Diker, G. (2017). Lisansüstü eğitim adaylanının akademik öz-yeterlik ve güdülenmelerinin incelenmesi (Cumhuriyet Üniversitesi örneği). Journal of Human Sciences, 14(2), 2129-2139. doi:10.14687/jhs.v14i2.4411

boyutu olan sosyal statü boyutunda adayların bölümlerine göre yapılan karşılaştırmada beden eğitimi öğretmenliği ve spor yöneticiliği arasında anlamlı farklllıklar bulunmuştur. Araştırma sonucunda cinsiyete göre akademik öz-yeterlik ve akademik güdülenme inançlarının değişmediği görülmüştür. Diğer bir sonuç olarak, araştırmaya katılan adayların medeni durumlarına göre akademik öz-yeterlik ve akademik güdülenme puanlarının farklılaşmadığı belirlenmiştir. Bunlara ek olarak lisansüstü eğitim adaylarının akademik öz-yeterlik ile akademik güdülenmeleri arasında yüksek düzeyde anlamlı ve pozitif ilişki bulunmuştur. Bu araştırmaya göre lisansüstü eğitim adaylarının akademik güdülenme düzeyleri arttıkça akademik öz-yeterlik düzeyleri de artmaktadır. Akademik güdülenme ile akademik işler için gereken enerji artarken, akademik öz-yeterlik sayesinde de birey kendi özelliklerinin farkına varmaktadır. Akademik güdülenmenin akademik öz-yeterliliği pozitif olarak etkilemesi bireylerin akademik alanda asla pes etmeyecekleri ve olumlu katkılar sağlayacaklarının bu çalışmaya göre göstergesi olarak söylenebilir. Bu araştırmaya göre, akademik hayata geçiş için 20-30 yaş aralığının ögrenciler için daha uygun olduğu ifade edilebilir.

\section{Kaynaklar}

Açıkgöz, K. Ü. (2007). Etkili Öğrenme ve Öğretme (7. Baskı). İzmir: Biliş.

Aggarwal, J. C. (2004). Essentials of Educational Psychology. New Delhi. Vikas Publishing House Pvt. Ltd.

Akbay, S. E., ve Gizir, C. A. (2010). Cinsiyete göre üniversite öğrencilerinde akademik erteleme davranış1: Akademik güdülenme, akademik öz-yeterlik ve akademik yükleme stillerinin rolü. Mersin Üniversitesi Eğitim Fakültesi Dergisi. 6(1). 60-78.

Akkoyunlu, B., ve Kurbanoğlu, S. (2004). Öğretmenlerin bilgi okuryazarlığ öz-yeterlik inancı üzerine bir çalışma. Hacettepe Üniversitesi Ë̆itim Fakülttesi Dergisi. 27.11-20.

Aydın, F. (2010). Akademik başarının yordayıcısı olarak akademik güdülenme. öz-yeterlilik ve sınav kaygısı. Yayımlanmamış Yüksek Lisans Tezi. Hacettepe Üniversitesi. Ankara.

Balaban Salı, J. (2006). Öğrenmede güdülenme İçinde: Y. Kuzgun ve D. Deryakulu (Ed.) Eğitimde bireysel farklılıklar (2. Baskı). Ankara: Nobel Yayın Dağıtım.

Balc1, A. (2001). Sosyal bilimlerde arasstrma: Yöntem. teknik ve ilkeler. Ankara: Pegem A Yayıncllk.

Bandura, A. (1977). Self-efficacy: Toward a unifying theory of behavioral change. Psychological Review. 84.191215.

Bandura, A. (1995). Self-efficacy in changing societies. New York: Cambridge University Press.

Bandura, A. (1997). Self-efficacy: The exercise of control. New York: W.H. Freeman and Company.

Bedel, E. F. (2016). Exploring academic motivation, academic self-efficacy and attitudes toward teaching in pre-service early childhood education teachers. Journal of Educationand Training Studies, 4(1), 142-149.

Bozanoğlu, İ. (2004). Akademik Güdülenme Ölçeği: Geliştirilmesi. geçerliği ve güvenirliği. Ankara Üniversitesi Egitim Bilimleri Fakültesi Dergisi. 37.83-98.

Çakır, Ö., Kan, A., ve Sünbül, Ö. (2006). Öğretmenlik meslek bilgisi ve tezsiz yüksek lisans programlarının tutum ve özyeterlik açısından değerlendirilmesi. Mersin Üniversitesi Eğitim Fakïltesi Dergisi. 2(1). 36-47.

Demirtaş, H., Cömert, M., ve Özer, N. (2011). Öğretmen Adaylarının Özyeterlik İnançları ve Öğretmenlik Mesleğine İlişkin Tutumlanı. Eğitim ve Bilim. 36(159).

Duy, B., Kaya, A. (2009). Güdülenme ve Bireysel Farkllllklar. Eğitim Psikolojisi. 473-511. Ankara: Pegem Akademi.

Eğmir, E., Ödemiş, İ. S., Bayar, V., Bayar, A., Kayır, G. (2013). Lisansüstü Eğitim Gören Öğrencilerin Akademik Güdülenme Düzeyleri. Sakarya Üniversitesi Eğitim Bilimleri Enstitüsü. VI. Ulusal Lisansüstü Eğitim Sempozyumu. Bildiri Kitabı. 95(6). 97-103.

Ekici, G. (2012). Akademik öz-yeterlik ölçeği: Türkçeye uyarlama. geçerlik ve güvenirlik çalışması. Hacettepe Üniversitesi Ë̆itim Fakültesi Dergisi. 43. 174-185.

Eymur, G. Geban, Ö. (2011). Kimya öğretmeni adaylarının motivasyon ve akademik başarıları arasındaki ilişkinin incelenmesi. Eğitim ve Bilim. 36(161). 246-255.

Fırat Durdukoca, Ş. (2010). Sınıf öğretmeni adaylarının akademik özyeterlik algılanının çeşitli değişkenler açısından incelenmesi. Abant İzzet Baysal Üniversitesi Dergisi. 10(1). 69-77.

Gençay, Ö. A.. Gençay, S. (2007). Beden eğitimi ve spor yüksekokulu öğrencilerinin öğretmenlik mesleğine ilişkin motivasyon düzeylerinin bazı değişkenler açısından incelenmesi. Selçuk Üniversitesi Sosyal Bilimler Enstitïsü Dergisi. 17(241). 241-253. 
Özgül, F., \& Diker, G. (2017). Lisansüstü eğitim adaylarının akademik öz-yeterlik ve güdülenmelerinin incelenmesi (Cumhuriyet Üniversitesi örneği). Journal of Human Sciences, 14(2), 2129-2139. doi:10.14687/ihs.v14i2.4411

Güven. İ. ve Tunç. B. (2007). Lisansüstü Öğrencilerinin Akademik Sorunları (Ankara Üniversitesi Eğitim Bilimleri Enstitüsü Örneği). Millı Ë̈itim. 173.157-172.

Karakütük, K. (2002). Ögrretim Üyesi ve Bilim Insam Yetiștirme Lisansïstü Öğretimin Planlanması. Ankara: Anı Yayıncilik.

Karataş, H., Erden, M. (2012). Akademik motivasyon ölçeğinin dilsel eşdeğerlik. geçerlik ve güvenirlik çalışması. e-Journal of New World Sciences Academy. 7(4). 983-1003. Lisansüstü Eğitim Öğretim Yönetmeliği. 22683 (Resmi Gazete 07 01. 1996).

Özsüer, S., İnal, G., Uyanık, Ö., Ergün, M. (2011). Afyon Kocatepe Üniversitesinde öğrenim gören öğrencilerin akademik özyeterlik inanç düzeylerinin incelenmesi. Sosyal Bilimler Dergisi. 13(2). 113-125.

Pintrich, P. R., \& Schunk. D. H. (1996). Motivation in education: Theory. research. and applications (2nd ed.).New Jersey:Prentice-Hall Inc.

Saracaloğlu, A. S. (2008). Lisansüstü Öğrencilerin Akademik Güdülenme Düzeyleri. Araştırma Kaygilan ve Tutumları İle Araştrma Yeterlikleri Arasındaki İlişki. Yüəz̈noü Yal Üniversitesi Eğitim Fakültesi Dergisi. 5(2). 179-208.

Semerci, Ç. ve Duman, B. (2013). Achievement Motivations of the Students Studying at Computer and Instructional Technologies Teaching Department. Mevlana International Journal of Education. 3 (1). 134142.

Şahin, H. ve Çakar, E. (2011). Eğitim Fakültesi Öğrencilerinin Öğrenme Stratejileri ve Akademik Güdülenme Düzeylerinin Akademik Başarllarına Etkisi. Türk Eğitim Bilimleri Dergisi. 9(3). 519-540.

Tabancalı, E., ve Çelik, K (2013). Öğretmen adaylarının akademik öz-yeterlikleri ile öğretmen öz-yeterlilikleri arasındaki ilişki. International Journal of Human Sciences. 10(1). 1167-1184.

Tekin, M., Taş̆ğın, Ö., Yıldız, M., Lök, S. (2009). 6. Ulusal Beden Eğitimi ve Spor Öğretmenliği Sempozyumu: Beden eğitimi ve spor yüksekokulunda öğrenim gören öğretmen adaylarının öğretmenlik mesleğine ilişkin motivasyon düzeyleri. Burdur: Mehmet Akif Üniversitesi.

Tural, N. (1993). Kimya Petrol ve Plastik Sanayinde Eğitim-İnsan gücü-İstihdam İlişkileri ve Buna İlişkin İşveren Görüşleri. Yayımlanmamış Doktora Tezi. Ankara Üniversitesi Eğitim Bilimleri Enstitüsü.

Turgut, M. (2013). Academic self- efficacy beliefs of undergraduate mathematics education students. Acta Didactica Napocensia, 6(1),33-39.

Türkiye Yükseköğretim Yeterlilikler Çerçevesi (2010). http://tyyc.yok.gov.tr/dosyalar/21122011TYYC\%20Yonetmeligi-Taslak.doc. Erişim tarihi: 15.01.2017.

\section{Extended English Abstract}

It is known that graduate education can provides various possibilities as; a wider range of jobs. good income and status. continue education. scientific literacy (Tural. 1995). Particularly. postgraduate education has important responsibilities in terms of raising the conclusions about the country problems and raising the high quality human power felt (Karakütük. 2002). However. it is the aim of the postgraduate education to educate individuals who are respectful to ethical values. who can produce creative solutions. who are prone to group work. able to adapt to the needs of society and who can respond to society's needs. On the other hand. post-graduate education presents some problems to its candidates. Economic problems are at the beginning of these problems (Tural. 1993). In addition to this problem. differences in human behavior are another curious problem. People have been investigating why they preferred certain movements while determining their actions up to years (Aç1kgöz. 2007). Motivation is a driving force that motivates and directs the individual to reach the specified goals and to show the necessary behaviors (Balaban Salı. 2006). Academic motivation is shortly defined as "the production of energy required for academic work" (Bozanoğlu. 2004). Thats why. it is important to determine the factors affecting students' motives and to take necessary precautions and especially to make learning and teaching processes more effective and efficient. in terms of academic success (Karataş ve Erden. 2012). Different definitions and explanations have been given related to Academic self- Efficacy. The prominent name of the concept is Bandura. Bandura (1997) defines self-efficacy as "individual's beliefs about organizing required events for a specific performance and the capacity of achieving a task". When the learning activities are considered. the academic self-efficacy perception is more prominent (Tabancalı ve Çelik. 2013). 
Özgül, F., \& Diker, G. (2017). Lisansüstü eğitim adaylarının akademik öz-yeterlik ve güdülenmelerinin incelenmesi (Cumhuriyet Üniversitesi örneği). Journal of Human Sciences, 14(2), 2129-2139. doi:10.14687/ihs.v14i2.4411

The aim of this research is to compare the academic self-efficacy and motivation of the health science institute post-graduate candidates according to the age, sex, graduated section and marital status variables. Also it was aimed whether postgraduate candidates' academic self-efficacy changes their academic motivaion levels significantly or not.

The model of this study is relational search. The sample of the research is composed of 100 students applying to the Physical Education and Sports Master program of the Institute of Health Sciences of Cumhuriyet University in 2016-2017 academic year. which is included in the research using appropriate sampling method. Two different scales were used to collect the data for the research. The Academic Self-efficacy Scale developed by Owen and Froman (1988) and translated into Turkish and tested for validity and reliability by Ekici (2012) and the academic motivation scale developed by Bozanoğlu (2004).

Permission has been obtained for the application of data collection tools used in the research. Before the application. necessary explanations were made on the purpose of the research and the candidates completed the Informed Voluntary Confirmation Forms. Subsequently. the scales were filled. the incorrectly filled forms were considered invalid. and the acceptable forms (100) were transferred to the computer for evaluation.

For the analyses of the data. SPSS 23.0 was used. In the evaluation of the data. parametric test assumptions were fulfilled (Kolmogorov-Smirnov). The sinificance level was taken as .05 and Variance Analyze. Tukey test. Independent Samples Test and Correlation Analysis were used.

When the academic self-efficacy subscale and total scores and total academic motivation scores of the students who participated in the research were compared according to age groups. significant differences were found in terms of both academic self-efficacy sub-dimensions and total scores as well as academic motivation total scores. These endorsements. in particular. indicated that academic self-efficacy scores differed by age in the work of Tabancalı and Çelik (2013). Durdukoca (2010) and Kllıç and Öncü (2013) also show that the average level of academic self-efficacy is above the middle level. Significant differences were found when examining social status subscale scores from the academic self-efficacy subscales of the study participants according to their graduation points. When the points are compared with each other. the difference between the physical education teacher and sport management departments is meaningful. whereas the difference between the coaching department is not significant. As a result of the research. it was determined that Total Academic Self-Efficacy and Total Academic Motivation scores did not differ according to gender. Saracaloğlu (2008). Eğmir et all. (2013). Çakar and Şahin (2011) and Semerci and Duman (2013) supported this result in their work.

As a result. the research group's academic self-efficacy and academic motivation perceptions were above the middle level. Significant differences were found in academic self-efficacy and motivation levels according to age. There were significant differences between the physical education teachers and the sports administrators in comparison with the sections of the candidates in terms of social status which is the academic self-efficacy sub-dimension. In addition. there is a high level of meaningful and positive relationship between academic self-efficacy and academic motivations of post-graduate candidates. According to this research. academic self-efficacy levels are increasing as the level of academic motivation of graduate education candidates increases. 